\title{
IRRIGATION WATER MANAGEMENT IN THE NILE DELTA USING GIS TECHNOLOGY
}

\author{
Ramadan M.H. ${ }^{1}$, M.M. Ibrahim ${ }^{2}$, N.A. Abd Elwarth ${ }^{3}$
}

ABSTRACT

A GIS-based decision support model was developed for On-farm Water Management (GIS-OWM). The model includes three modules for water requirements calculations; crops manipulation and On-farm Water Allocation. The model was verified in an area located between Dakahlia and Kafr Elsheikh governorates, Egypt during (1/10/2013 to 1/10/2014). The ETo values which were estimated using GIS-OWM were highly significantly correlated with the ETo values estimated using FAO CROPWAT. The consumed time to reach the selected gates on Bahr Elbeshma canal using the GIS-OWM model were also highly significantly correlated with the actual consumed time to reach the same gates. The forecasting gross irrigation requirements for the pattern distributed using GIS-OWM $\left(\mathrm{m}^{3}\right)$ was compared to the canals available water $\left(\mathrm{m}^{3}\right)$ and the gross irrigation requirements for the actual pattern $\left(\mathrm{m}^{3}\right)$. The saved water amount during summer season when GIS-OWM is verified is $\left(1.22 \times 10^{7}\right)$ $m^{3}$ for 11795 Feddans. This amount represents about $34.6 \%$ of total water available during this period. GIS-OWM is able to generate maps for Onfarm Water Allocation and field irrigation status.

\section{INTRODUCTION}

$\mathrm{P}$ recision agriculture is generally defined by Mandal and Maity (2013) as information and technology based farm management system to identify, analyze, and manage variability within fields for optimum profitability, sustainability and protection of the land resource. Precision farming aims to manage production inputs over many small management zones rather than on large zones. Water management requires many factors to reach optimal distribution for water such as soil data, crops data, metrological data, and irrigation water networks data. Penman - monteith method is the standard method for reference crop evapotranspiration (ETo) calculations were reported by Allen et al. (1998).

1 Prof. and 2 Assistant Prof. of Agric. Eng. Dept., Faculty of Agric, Al-Mansoura Univ.

${ }^{3}$ Agric. Engineer, Agric. Eng. Res. Institute (AEnRI) - El-Dokki, Cairo. 
Smith (1992) developed a model (CROPWAT) for calculations of reference evapotranspiration, crop water and irrigation requirements. The effective system to relate all factors is geographic information systems (GIS). There are many models based on GIS are developed for ETo calculation. Bandyopadhyay et al. (2012) ) developed an ArcGIS toolbar for forecasting daily evapotranspiration, rainfall and net irrigation requirements (NIR) of India and then generated ETo and (NIR) maps. While Espana et al. (2011) developed a GIS tool called "ArcE" to calculate actual evapotranspiration $\left(\mathrm{E}_{\mathrm{A}}\right)$ and potential evapotranspiration $\left(\mathrm{E}_{\mathrm{P}}\right)$ sequentially from monthly perception $(\mathrm{P}, \mathrm{mm})$, average daily air temperature $\left(\mathrm{T},{ }^{\circ} \mathrm{C}\right)$, and daily range of air temperature $\left(\mathrm{T},{ }^{\circ} \mathrm{C}\right)$ data using an undefined number of meteorological stations. Ray and Dadhwal (2000) developed a tool using ArcGIS to estimate seasonally realistic spatial crops evapotranspiration. The Kc and ETo maps were combined to generate seasonal ETc. Todorovic and Steduto (2003) developed a spatial modeling of GIS-based irrigation planning and management. Irrigation requirements in this model was estimated by taking into account different scenarios of cropping pattern, climatic conditions, applied irrigation method, volume of water available for irrigation and hydraulic characteristics of the water distribution system.

Currently GIS is famous for its various applications in on-farm water allocation. Wen et al. (2004) developed a model framework of regional irrigation water demand assessment using GIS. It is a tool for improving demand planning by setting up different scenarios and revealing the impacts under those scenarios to search for the one with the least negative impact. Bustamante et al. (2007) developed a tool using spatial information system to improve water management in Mexico. The tool used to forecast seasonal water demands at the beginning of each water year. This tool also generated maps of field irrigation status. The types of these maps were in-progress, future and postponed. Postponed maps were divided into two subtypes; delay and urgent irrigation. Manna (2000) developed a GIS-based irrigation scheduling and on farm water allocation program for irrigated crops. Water is allocated to the fields based on this priority setting, water availability and irrigation system constraints. The GIS program will automatically transfer the fields that were left without 
irrigation to the next day.Wong (2004) developed a model for water allocation using GIS included water allocation scenarios. The scenarios created based on the demands of the crops grown on fields and the available water supply for agriculture within the watershed.

One of the main challenges for farmers in the study area is that water is not available permanently during seasons. The major problem of area is water shortage in several zones especially at ends of canals due to the increase in rice cultivation. Rice area contributes to almost $60 \%$ of total area. The reason of that increase may be due to the return benefits of rice price.

The main objective of the study was to develop A GIS-based decision support model for On-farm Water Management (GIS-OWM). The model aims to efficiently allocation for water and crops.

\section{METHODOLOGY}

\section{Study area}

The study area (Figure 1) is located between Dakahlia and Kafr Elsheikh, Governorates, Egypt $\left(31.22^{\circ}-31.33^{\circ} \mathrm{N}, 31.23^{\circ}-31.3^{\circ} \mathrm{E}\right)$. It is classified as clay soil where Rice, Cotton, Maize and vegetables are cultivated in summer season. While in winter season crops are: Wheat, Clover, Sugar Beet, Potatoes, Fababean, and Flax. The salinity of the applied irrigation water is $0.60 \mathrm{dS} / \mathrm{m}$.

The area is classified as an arid region because the rainfall varies from as minimum as $0.0 \mathrm{~mm}$ in July to a maximum of $40 \mathrm{~mm}$ in January. The main water resource comes from the river Nile.

Water is distributed via the rotational systems among sub canals. The area contains sub canal (bahr elbeshma) and its six distributaries. The net served area for the canals: Bahr elbeshma (direct irrigation), Seryowa, Elshtoot, Habeeb, Alkomsewon, Elkatf, and Roos elferakh are 4078.0, 976.10, 1175.68, 1033.75, 1864.27, 1743.42 and 923.75 Feddans respectively, the total net served area is 11795 Feddans $\left(5 \times 10^{7} \mathrm{~m}^{2}\right)$.

\section{GIS-OWM Model developement}

ArcMap 10.1 was utilized to perform the integration between GIS and On-Farm Water Management. The model was developed using ArcObjects .NET 10.1 SDK and Microsoft visual studio 2010. 


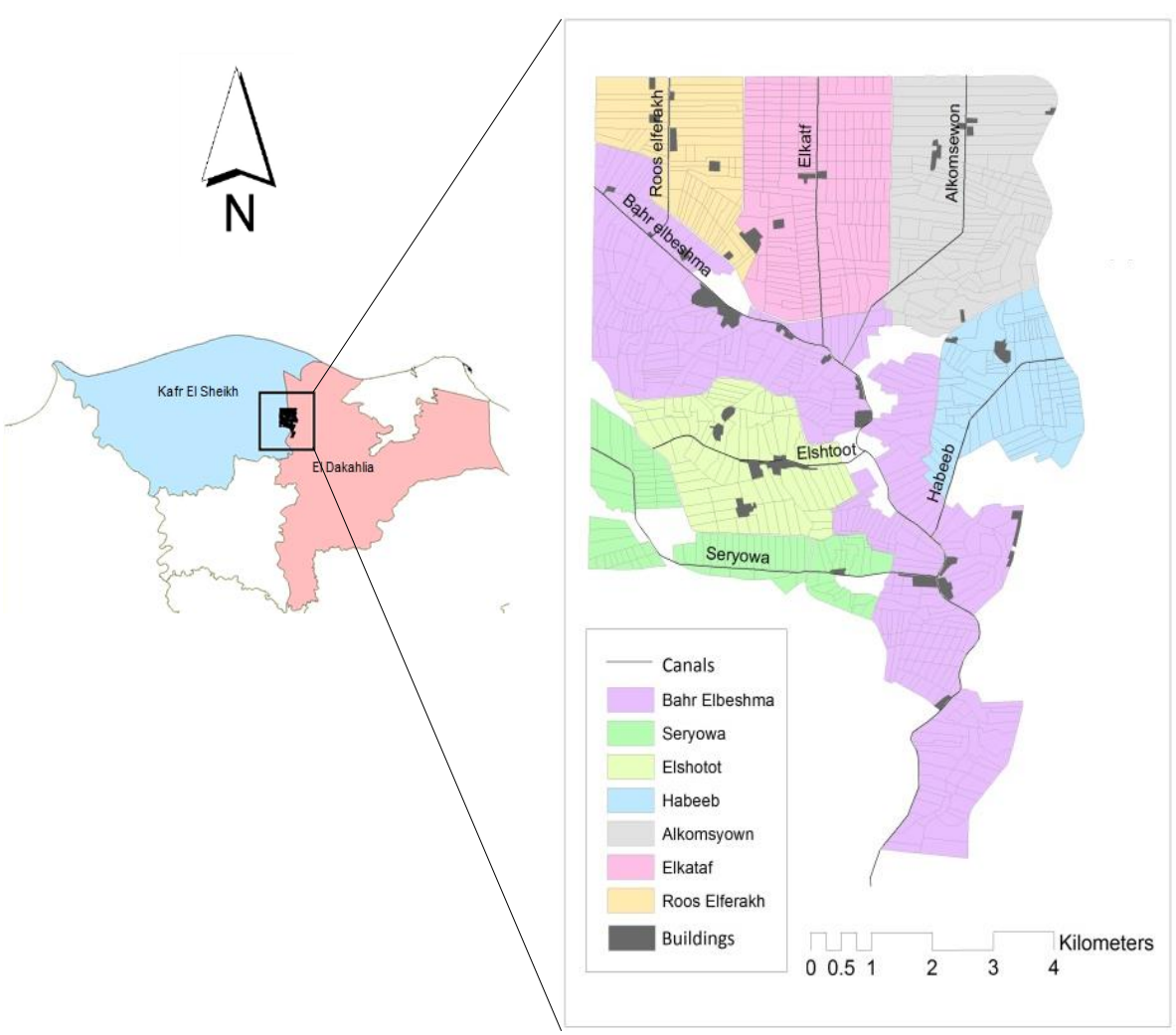

Figure (1): Location of the study area $\left(31.22^{\circ}-31.33^{\circ} \mathrm{N}, 31.23^{\circ}-31.3^{\circ} \mathrm{E}\right)$

\section{First module: Water requirements calculations}

The following calculation steps are based on (FAO 56) reported by Allen, et al. (1998).

- Calculating the reference evapotranspiration (ETO) using FAO PenmanMonteith method as the standard method for definition and computation of using weather data such as radiation, air temperature, air humidity and wind speed. In addition to data related to location (latitude and elevation above sea level), using daily, ten days, or monthly data.

$$
E T_{0}=\frac{0.408 \Delta\left(R_{n}-G\right)+\gamma \frac{900}{T+273} u_{2}\left(e_{s}-e_{a}\right)}{\Delta+\gamma\left(1+0.34 u_{2}\right)}
$$

Where; $E T_{0}$ : Reference evapotranspiration ( $\mathrm{mm} /$ day), $R_{n}:$ Net radiation at the crop surface (MJ $m^{-2}$ day $^{-1}$ ), G: Soil heat flux density (MJ $\mathrm{m}^{-2}$ day $\left.^{-1}\right), \mathrm{T}$ : Mean daily air temperature at $2 \mathrm{~m}$ height $\left({ }^{\circ} \mathrm{C}\right)$, 
$u_{2}$ : Wind speed at $2 \mathrm{~m}$ height $(\mathrm{m} / \mathrm{s}), e_{s}$ : Saturation vapour pressure $(\mathrm{kPa}), e_{a}$ : Actual vapour pressure $(\mathrm{kPa}), e_{s}-e_{a}$ : Saturation vapour pressure deficit $(\mathrm{kPa}), \Delta$ : Slope vapour pressure curve $\left(\mathrm{kPa} /{ }^{\circ} \mathrm{C}\right)$, and $\gamma$ : Psychometric constant $\left(\mathrm{kPa} /{ }^{\circ} \mathrm{C}\right)$

- Calculating the crop evapotranspiration $\left(E T_{c}\right)$ depends on the type of crop and growth stages and are also applicable to areas of similar climate. The crop coefficient $\left(k_{c}\right)$ represents the ratio of $E T_{c}$ to ETo:

$$
E T_{c}=E T_{o} \times K_{c}
$$

$k_{c}$ can be divided into three distinct growth stages: initial, mid-stage and end stage. $\left(K_{C \text { ini }}, K_{C \text { mid }}\right.$, and $\left.K_{C \text { end }}\right)$.

- Calculating the Readily available water (RAW) with following equation

$$
R A W=\left(A W \times Z_{r}\right) \times p
$$

Where; AW: Available water holding capacity $(\mathrm{mm} / \mathrm{m}), Z_{r}$ : Development stage effective root zoon depth, $(\mathrm{mm})$, and $\mathrm{p}=$ evapotranspiration depletion factor $(\%)$. (p) Is the average fraction of Total Available Soil Water (TAW) that can be depleted from the root zone before moisture stress (reduction in ETo) occurs.

The readily available soil water is the fraction of Total Root zone Available water that a crop can extract from the root zone without suffering water stress. Where the soil is sufficiently wet, the soil supplies water fast enough to meet the atmospheric demand of the crop, and water uptake equals $\mathrm{ET}_{\mathrm{c}}$.

- The Soil water depletion is identified from the following equation:

$$
D_{i}=D_{i-1}+\left(E T_{c}-R\right)_{i}
$$

Where; $D_{i}$ : Soil water depletion $(\mathrm{mm})$ on day $\mathrm{I}, D_{i-1}$ : Soil water depletion on day i-1 (mm), and R : Effective rainfall (mm)

Irrigation time can be determined when $D_{i}$ value is equal to or exceed the readily available water. (RAW) The amount of water will be added to the soil is equal to soil water depletion taking into account leaching requirements and field application efficiency. 
- Calculating the Leaching Requirements calculation (LR) according to Ayers and Westcot. (1985).

$$
L R=\frac{E C_{w}}{5 E C_{e}-E C_{w}}
$$

Where; $E C_{w}$ : Electrical conductivity of the irrigation water $(\mathrm{dS} / \mathrm{m})$, and $E C_{e}$ : Electrical conductivity of the soil saturation extract $(\mathrm{dS} / \mathrm{m})$.

The leaching requirement is the minimum fraction of the total applied and infiltrated water (irrigation plus precipitation) that must pass through the crop root zone to prevent a reduction in yield from excessive accumulation of salts.

- According to Allen, et al. (1998) the Gross irrigation water depth $\left(D_{g}\right)$ is calculated using the following equation

$$
D_{g}=\frac{D_{i}}{E_{a}(1-L R)}
$$

Where; $D_{g}$ : Gross irrigation water depth $(\mathrm{mm})$, and $E_{a}$ : Field application efficiency $(\%)$

The calculation is based on the concept of management allowed depletion (MAD) of the available water that can be stored in the root zone.

\section{Rice irrigation case}

Rice irrigation is different from other crops; it is grown under flooded conditions. The following steps to calculate rice gross irrigation water depth based on Brouwer and Heibloem (1986)

- Calculating the soil water depletion for rice by the following equation

$$
D_{r i}=D_{r i-1}+\left(E T_{c}+P E R C\right)_{i}
$$

Where; $D_{r i}$ : Rice soil water depletion $(\mathrm{mm})$ on day I, $D_{r i-1}$ : Rice soil water depletion on day i-1 (mm), and PERC: The amount of percolation and seepage losses $(\mathrm{mm})$. The percolation and seepage losses values are $r$ $\bullet, 8 \mathrm{~mm} /$ day for heavy clay, medium and sandy soils based on assumption according to Brouwer and Heibloem (1986)

The depth of water will be added to the soil is identified from the following equation 


$$
D_{g}=\frac{D_{r i}}{E_{a}(1-L R)}
$$

- The amount of water that added before planting for rice to saturate the root zone for land preparation by puddling is calculated by the following equation

$$
D_{g}=\frac{S A T}{E_{a}(1-L R)}
$$

Where; SAT : the depth of water added to saturate the soil $=200 \mathrm{~mm}$, based on assumption according to Brouwer and Heibloem (1986)

- Calculating the water layer amount for rice which is established on start of mid-season stage and maintained throughout the growing season by the following equation

$$
D_{g}=\frac{W L}{E_{a}(1-L R)}
$$

Where; WL : The amount of water needed to establish a water layer $=100$ $\mathrm{mm}$, based on assumption according to Brouwer and Heibloem (1986).

The amount of water needed for maintaining the water layer has already been taken into account with the determination of the percolation and seepage losses.

\section{Second module: Crops manipulation}

The module was developed for manipulating the optimal cropping pattern for all the crops grown in the study area. The optimal cropping pattern insures that the amount of total water would be allocated among crops during the season must be less than or equal to the available water amount through the canal discharge. The following calculation steps for crops manipulation:

- Calculating the Canal's Available Water amount (CAW) will be carried on the canal during rotation On-time period from the following equation

$$
C A W=Q_{f} \times A_{f} \times l_{\text {on }}
$$

Where; $Q_{f}$ : Amount of water determined for Feddan $\left(\mathrm{m}^{3}\right)=45 \mathrm{~m}^{3}$ / Feddan/day based on the assumption according to the ministry of water 
and irrigation, $A_{f}$ : Canal served area (Feddan), and $l_{o n}$ : Length of ontime period of rotation (day)

- Crop gross irrigation water requirements (GIR) is calculated for all ON Times throughout the year based on the original standard according to the following equation

$$
G I R=\frac{D_{g} \times A_{c} \times 4200}{1000}
$$

Where; GIR: Gross irrigation water requirements $\left(\mathrm{m}^{3}\right), D_{g}$ : Gross irrigation water depth, $\mathrm{mm}$ (saved from previous module), and $A_{c}$ : The area of crop that's entered to the tool $\left(\mathrm{m}^{2}\right)$.

The area of every crop (Feddans) or percentage of the canal's served area is entered manually to the crops manipulation tool. The irrigation times and amount of water needed to be added were saved to the geodatabase from the first module.

- Calculating the total Gross irrigation water requirements (TGIR) for all crops on the canal's served areas that will be irrigated in the same ON Time by the following equation

$$
T G I R=\sum G I R_{c 1}, G I R_{c 2}, G I R_{c 3}, \ldots G I R_{c n},
$$

Where; $G I R_{c}$ : Gross irrigation water requirements for crop $\left(\mathrm{m}^{3}\right)$, and $\mathrm{n}$ : number of crops have irrigation in the same rotation on- time period.

\section{The cropping pattern}

After inserting the crops' area, the total gross irrigation water requirements for each ON Time for the canal served area is compared to the available water amount of the same canal in sequence throughout the two seasons. If TGIR < CAW for all ON Times, the pattern could be submitted. If TGIR > CAW in one or more ON Times, a message to retry the pattern will appear.

\section{The spatial crops manipulation}

A spatial crops manipulation tool is developed to manipulate crops pattern that is submitted in the previous step to the fields into the map. Crops are manipulated into groups to avoid overlapping in the planting date. Each group contains a summer crop and a winter crop. 
The determination of the suitable crops groups requires revising the history of the field for the previous years. Then, the summer and the winter crop patterns are separated into two layers for each season.

The crop group for any field could be changed according to the farmer's preference using spatial crops manipulation tool. If this procedure increases the total crops irrigation requirements than the total available water amount, it can alternate the crops group of the field with another field.

\section{Third module: On-farm Water Allocation}

The module is considered as a decision support tool for water allocation. In this module, dynamic maps for field irrigation status and On-farm Water Allocation are generated. The On-farm Water Allocation dynamic maps demonstrate the total gross irrigation water required by fields during the ON Time. The field irrigation status dynamic maps illustrate the irrigation status during the ON Time (irrigated / in-progress / nonirrigated) refers to the fields already have finished, fields are still in irrigation progress, and fields that haven't been irrigated yet. These maps are determined according to the starting and the finishing irrigation time for every field. The starting or finishing irrigation time is added to time when the ON Time is started.

Furthermore, selection tools to make query for canals and fields data using customize selection tools on map are developed. The available data for the canals are: successive location downstream $(\mathrm{km})$ from the start of the canal, water level $(\mathrm{cm})$ and water velocity $(\mathrm{m} / \mathrm{sec})$. However the available data for fields are: field area $\left(\mathrm{m}^{2}\right)$, crop name, planting and harvesting date, available water depth $(\mathrm{mm})$ in the time selected, next irrigation time, next gross irrigation requirements (GIR) $\left(\mathrm{m}^{3}\right)$, field status (irrigated - in progress - non irrigated) and time of finishing irrigation. The calculation steps were applied for all points on the study area map as follow:

\section{Gross irrigation water requirements for fields $\left(G I R_{f}, m^{\mathbf{3}}\right)$}

$G I R_{f}$ for a field is estimated by (equation 12). Gross irrigation water depth $D_{g}$ for all crops was estimated using first module (Water 
requirements calculations). Thus; it was saved into the geodatabase. Crops were allocated spatially using second module (crops manipulation). Suggested new pattern was also saved into the geodatabase. Therefore, gross irrigation water depth $D_{g}$ can be identified for all fields. The Onfarm Water Allocation dynamic maps could be generated after this step.

\section{Water velocity Calculation}

Manning's equation is used in determining the average velocity $\left(V_{s}, m /\right.$ sec) in a canal segment section according to Ali (2011),

$$
V_{s}=\frac{1}{n} R^{\frac{2}{3}} S^{\frac{1}{2}}
$$

Where; R: Hydraulic radius, S: Slope of the water surface or the linear hydraulic head loss $(\mathrm{m} / \mathrm{m})$ and $\mathrm{n}$ : Manning coefficient, the value of $n$ indicates not only the roughness of the sides and bottom of the channel, but also other types of irregularities of the channel, such as alignment and vegetation. Canals lines are divided into segments according to the bed width and slope of the water surface.

\section{Hydraulic radius $(R)$ calculation}

The hydraulic radius $(\mathrm{R})$ is calculated based on the original standard. $\mathrm{R}$ was calculated by the following equations

$$
\begin{aligned}
R & =\frac{A}{P_{W}} \\
\mathrm{~A} & =\mathrm{B} \times \mathrm{D}+\mathrm{Z} \cdot \mathrm{D}^{2} \\
P_{W} & =B+2 D \sqrt{1+Z^{2}}
\end{aligned}
$$

Where; A: Canal cross section area $\left(\mathrm{m}^{2}\right)$, $\mathrm{Pw}$ : Canal wetted perimeter $(\mathrm{m})$, B: Canal bottom width $(\mathrm{m})$ and $\mathrm{z}:$ Side slope $=\frac{Y}{X}(\mathrm{~m})$

Determining the distance between the gates and the beginning of the segments

Distance between each gate and the beginning of the segment was determined on the canals layer separately by measurement on the map.

\section{Consumed flow time to reach each gate at the network $\left(T_{g}\right)$}

The consumed flow time to reach each a gate at the network $\left(T_{g}\right)$ is calculated by the following equation

$$
T_{g}=\sum T_{s 1}, T_{s 2}, \ldots ., T_{s n}, T_{c},
$$


The consumed flow time between the beginning of the segment and the gate $\left(T_{c}\right)$ is estimated by the following equation:

$$
T_{c}(\mathrm{sec})=\frac{L_{C}}{V_{s} \times E_{c}}
$$

Where; $L_{C}$ : Distance between the gate and the beginning of the segment $(\mathrm{m}), V_{s}$ : Water velocity through the segment $(\mathrm{m} / \mathrm{s})$, and $E_{c}$ : Conveyance efficiency (\%), based on assumption according to Brouwer et al. (1989) The consumed flow time through the segment $\left(T_{S}\right)$ is calculated by the following equation

$$
T_{S}(\mathrm{sec})=\frac{L_{S}}{V_{S} \times E_{c}}
$$

Where; $L_{s}$ : Length of the segment, (m)

Field's finishing irrigation time $\left(T_{f}\right)$

Time to finish irrigation for a field $\left(T_{f}\right)$ is calculated by following equation

$$
T_{f}=\frac{G I R_{f}}{Q}
$$

Where; Q : Water resource discharge $\left(\mathrm{m}^{3} / \mathrm{sec}\right)$

\section{Time to start irrigation for a field $\left(T_{f s}\right)$}

Time to start irrigation for a field $\left(T_{f s}\right)$ from the beginning of ON Time is calculated according to following equation:

$$
T_{f s}=\sum T_{g}, T_{f 1}, T_{f 2}, \ldots . T_{f n}
$$

Where; $\mathrm{n}$ : field irrigation sort into the district. The district is a group of fields has the same gate.

\section{GIS-OWM flowchart}

Steps for developing GIS-OWM are illustrated on Figure (2).

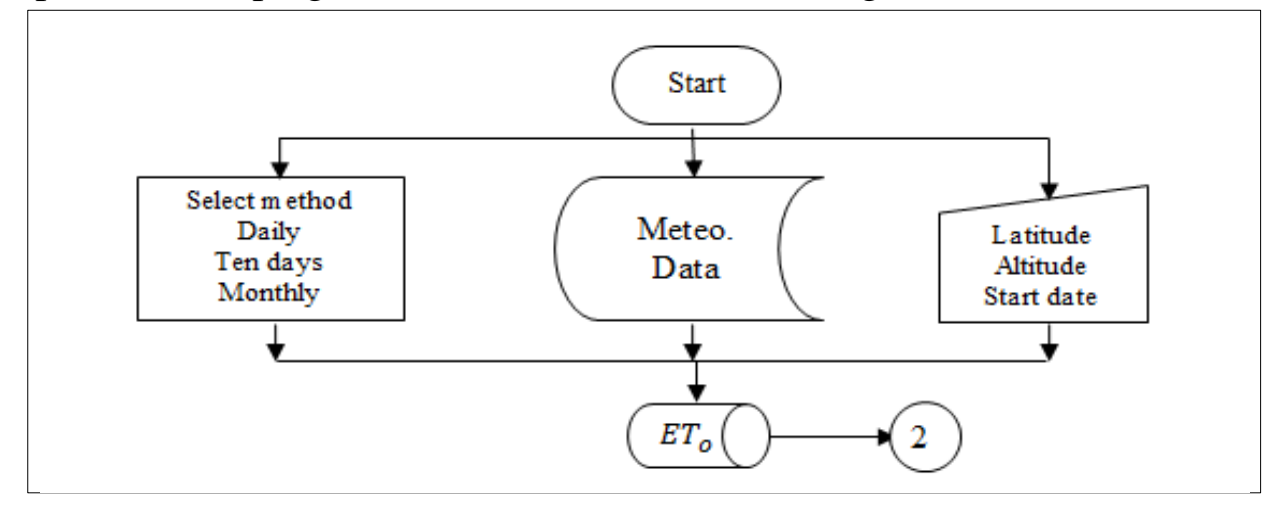

Figure (2): GIS-OWN flowchart 

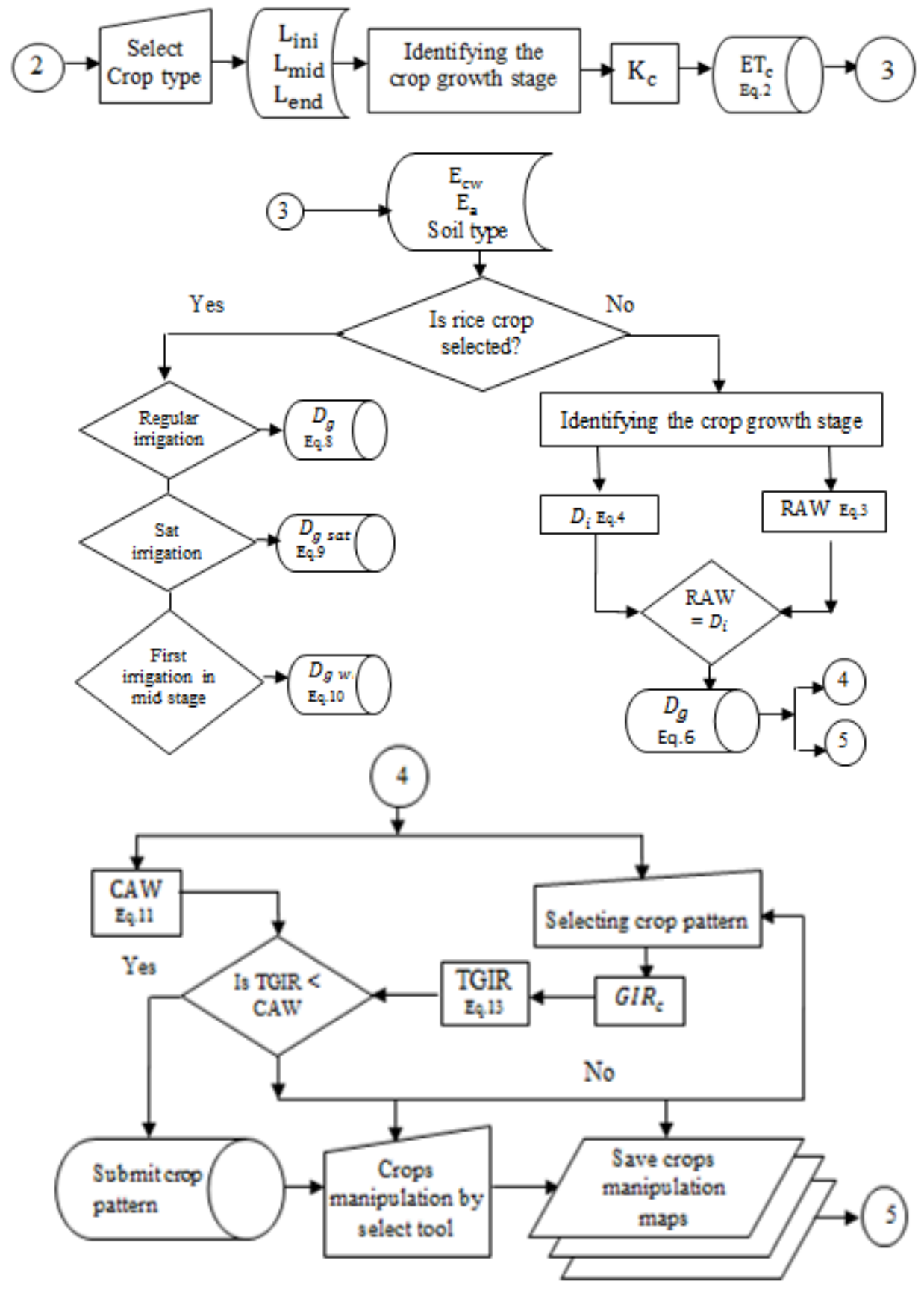

Continued Figure (2) 


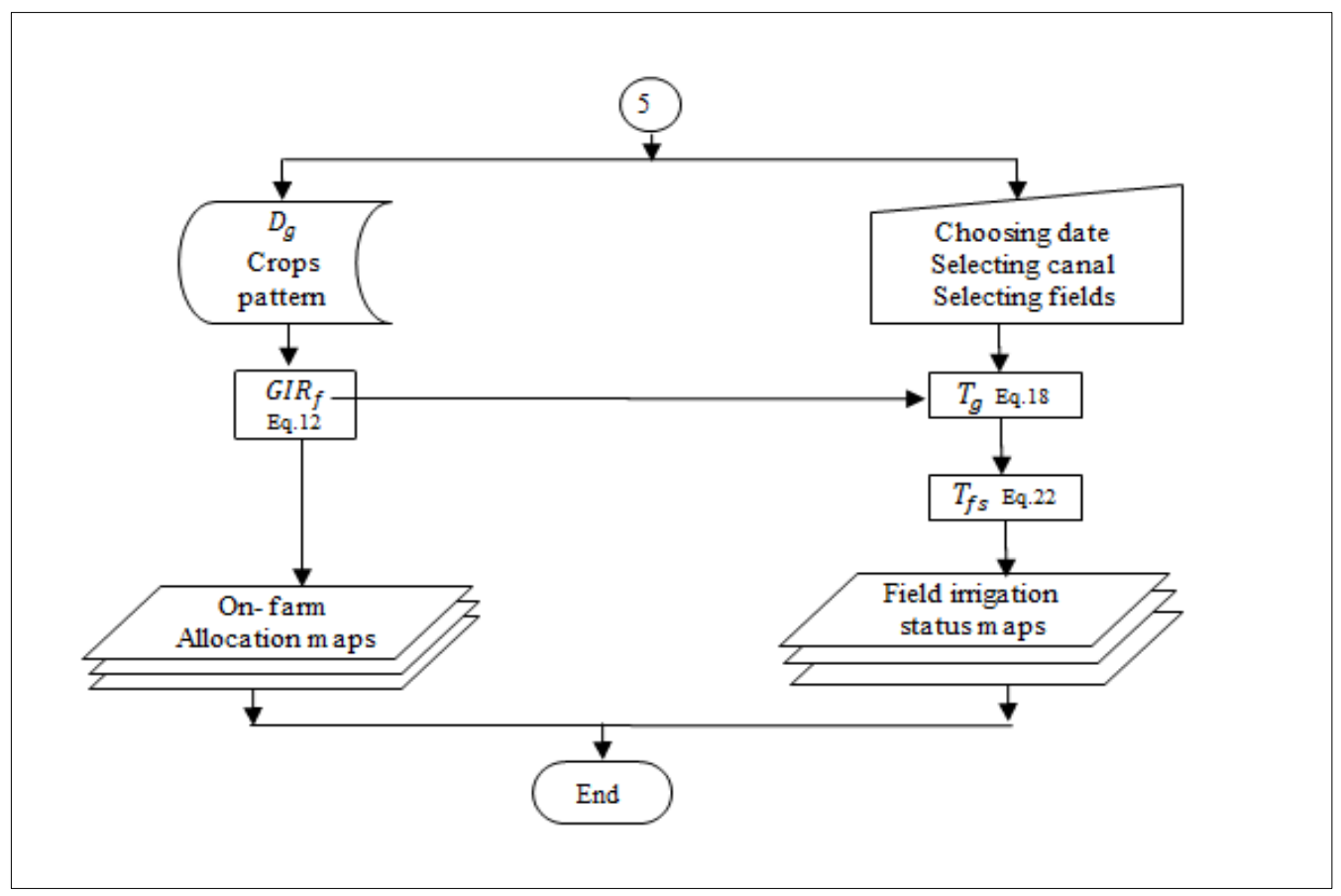

Continued Figure (2)

\section{RESULTS AND DISCUSSION}

\section{GIS-OWM model verification}

In order to verify the evapotranspiration calculation, the relationship between the ETo predicted values of GIS-OWM and the ETo values of FAO CROPWAT developed by Smith, (1992) during January is shown in Figure (3). The regression trend line during January is linear. The slope of the regression line provides a measure of the accuracy of the tool output. The value of the slope is 0.9792 (less than 1). The regression correlation coefficient (R) was 0.9996 .

According to the analysis of the variance, the mean square of the residual error was very small (i.e.0.0008). The calculated F value was 36132.19. This means that $\mathrm{F}$ value is high significant at $1 \%$ level.

On-farm Water Allocation module also was verified. The relationship between the consumed time to reach the selected gates on Bahr Elbeshma canal using the GIS-OWM model and the actual consumed time to reach the same gates is shown in Figure (4). 


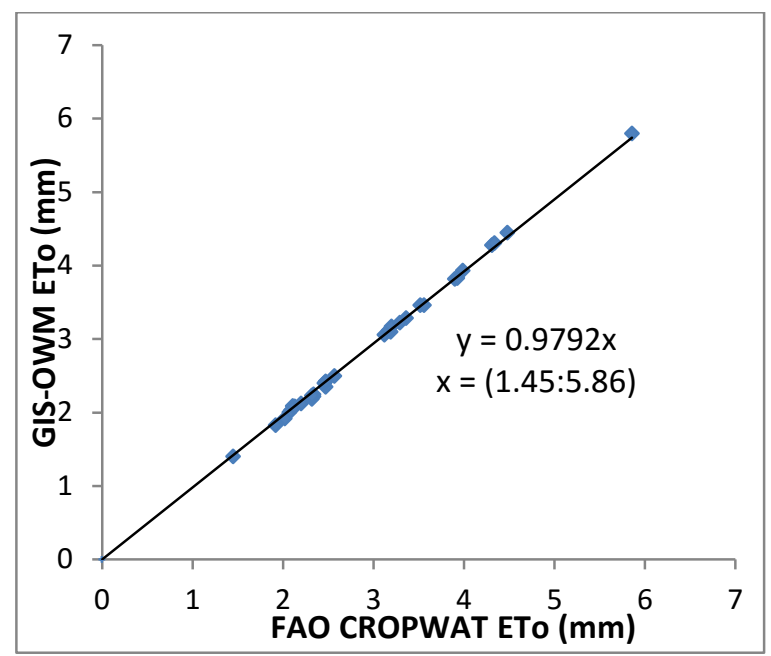

Figure (3): The relationship between GIS-OWM ETo predicted values and FAO CROPWAT ETo predicted values during January

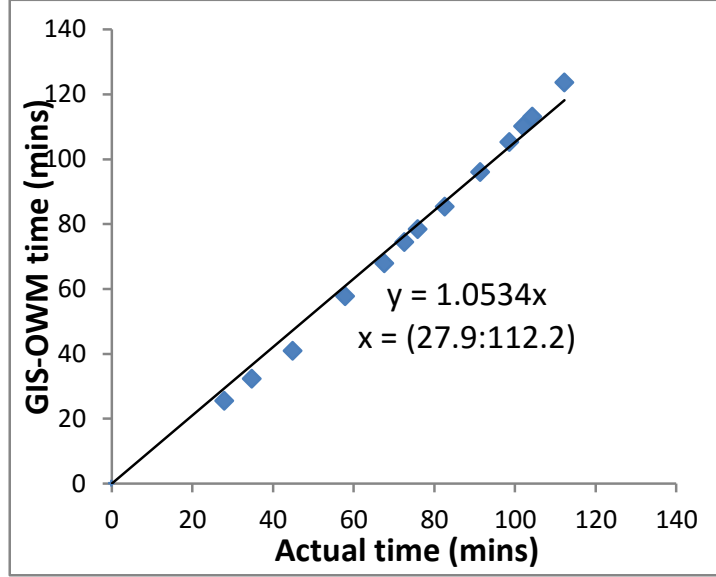

Figure (4): The relationship between the consumed time to reach the selected gates on Bahr Elbeshma canal using GIS-OWM model and the actual consumed time to reach the same gates.

The GIS-OWM consumed time to each gate was calculated according to Manning equation reported by Ali (2011). However the actual consumed time was calculated according to the measured water velocity $(\mathrm{m} / \mathrm{sec})$ using a currentmeter. The regression trendline is linear. The slope of the regression line provides a measure of the accuracy of the model output. The value of the slope is 1.0534 (more than 1). Significant linear relationship was attained with high accuracy of the regression correlation coefficient (R) was 0.999 . 
According to the analysis of variance for this relationship, the calculated $F$ value was 5533.33. The mean square of the residual error was very small (i.e. 2.2).

\section{Case study}

The main problem of the study area is the randomized cropping pattern. Most of the farmers and fields' owners tend to cultivate rice. Therefore, the peak water use occurs during summer season.

The actual pattern of the crops that are cultivated in the study area was allocated spatially using GIS-OWM. After that, the gross irrigation water requirements were calculated. The gross irrigation water requirements for the actual pattern are higher than the total available water amount on rotations no. $17,18,19,20,21,24$, and 27 . The total available water amount was calculated by summation of the canal's available water amount (CAW) for each canal that is calculated using (equation 11). The total amount of the deficit on these rotations equal approximately $2.94 \times$ $10^{6} \mathrm{~m}^{3}$ for the study area. The deficit percent is about $16.6 \%$ of the available water amount.

Table (1): The total amount of the water deficit required for the each rotation

\begin{tabular}{|c|c|c|}
\hline No. of rotation & Water deficit $\left(\mathrm{m}^{3}\right)$ & Deficit percentage $(\%)$ \\
\hline 17 & $2.9 \times 10^{5}$ & 10.0 \\
\hline 18 & $2.8 \times 10^{4}$ & 1.0 \\
\hline 20 & $1.8 \times 10^{8}$ & 63.7 \\
\hline 21 & $1.4 \times 10^{5}$ & 4.8 \\
\hline 24 & $4.2 \times 10^{5}$ & 14.0 \\
\hline 27 & $1.8 \times 10^{5}$ & 6.2 \\
\hline
\end{tabular}

As shown in Table (1), the highest gross water requirements for the total area were during rotation no. 20. The deficit amount equal approximately $1.8 \times 10^{8} \mathrm{~m}^{3}$, the percentage of the deficit is $63.7 \%$ of the available water amount during the rotation.

\section{The pattern of the water deficit amount during peak water use under actual pattern}

Figure (5) shows the deficit of water amount per Feddan on fields which have shortage of water for the study area under the currently randomized pattern. There was 8066 Feddans that suffered water deficit throughout summer season. The highest deficit in water equals approximately 1319 $\mathrm{m}^{3}$ per Feddan, the lowest was $134 \mathrm{~m}^{3}$ per Feddan, and the average was 459 $\mathrm{m}^{3}$ per Feddan. 


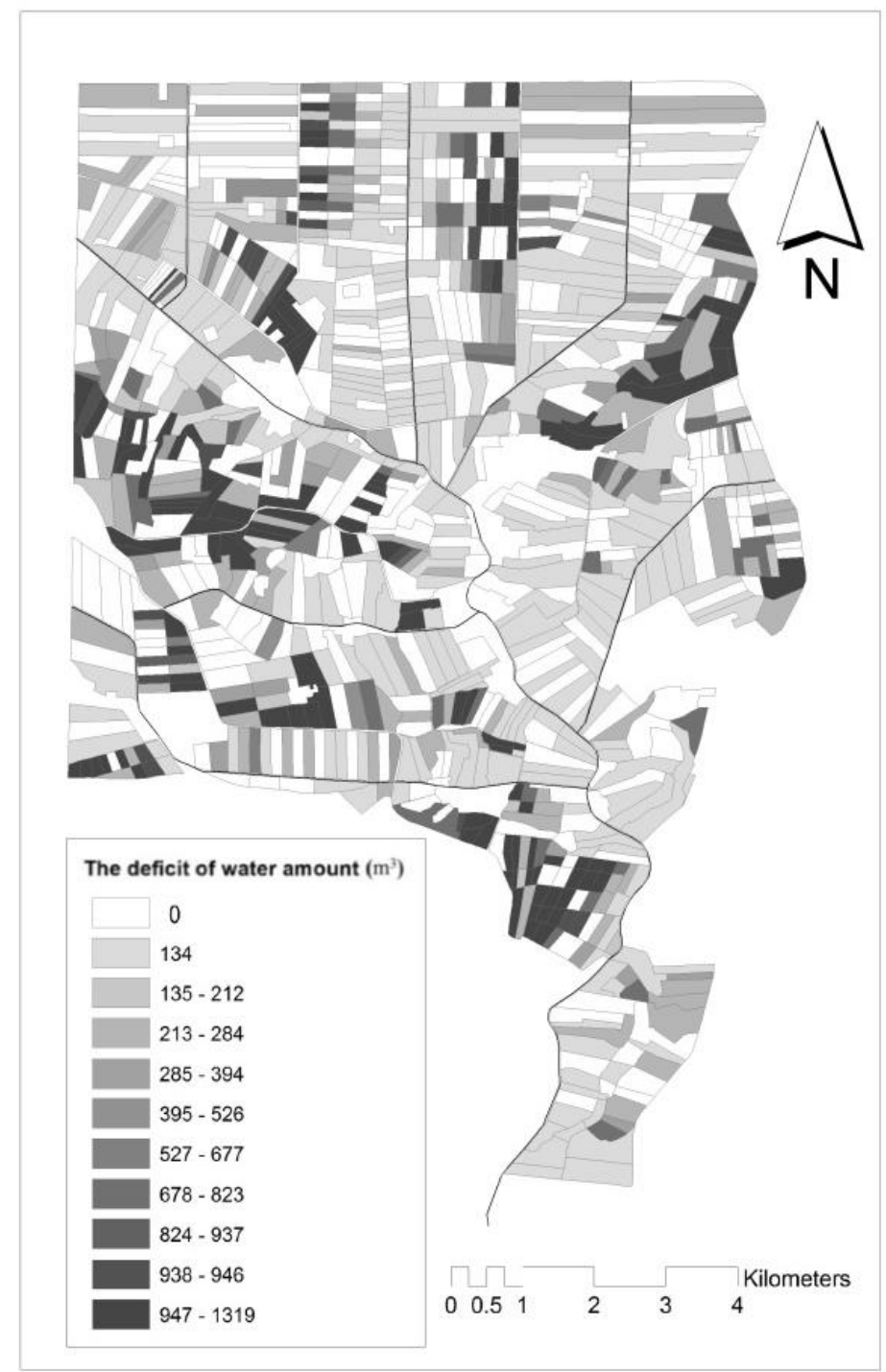

Figure (5): The water deficit $\left(\mathrm{m}^{3}\right)$ per Feddan on the fields which have shortage of water under the actual pattern.

\section{The number of missed irrigations}

The missed irrigation is the irrigation doesn't apply to the field due to water shortage. Table (2) shows the number of missed irrigation for fields, the number of fields that missed the same number of irrigations, the total area of fields, the percentage of these fields area (\%), and the amount of deficit water $\left(\mathrm{m}^{3}\right)$, the highest number of missed irrigations per field is 8 irrigations. 
Table (2): The number of missed irrigations under the actual cropping pattern.

\begin{tabular}{|c|c|c|c|c|}
\hline No. & No of fields & Area (Feddans) & Area percentage $(\%)$ & Deficit water $\left(\mathrm{m}^{3}\right)$ \\
\hline 0 & 278 & 3730 & 29.4 & 0 \\
\hline 1 & 321 & 4570 & 34 & $6.8 \times 10^{5}$ \\
\hline 2 & 89 & 1260 & 9.4 & $3.24 \times 10^{5}$ \\
\hline 3 & 35 & 340 & $3 . \vee$ & $1.4 \times 10^{5}$ \\
\hline 4 & 59 & 535 & 6.2 & $4 \times 10^{5}$ \\
\hline 5 & 36 & 273 & 3.8 & $2.4 \times 10^{5}$ \\
\hline 6 & 79 & 720 & 8.4 & $7.68 \times 10^{5}$ \\
\hline 7 & 43 & 332 & 4.5 & $3.9 \times 10^{5}$ \\
\hline 8 & 4 & 36 & 0.5 & $4.7 \times 10^{4}$ \\
\hline
\end{tabular}

Figure (6) illustrates the pattern of missed irrigations per field into the study area map. Therefore, it is necessary to change this pattern with another one using GIS-OWM.

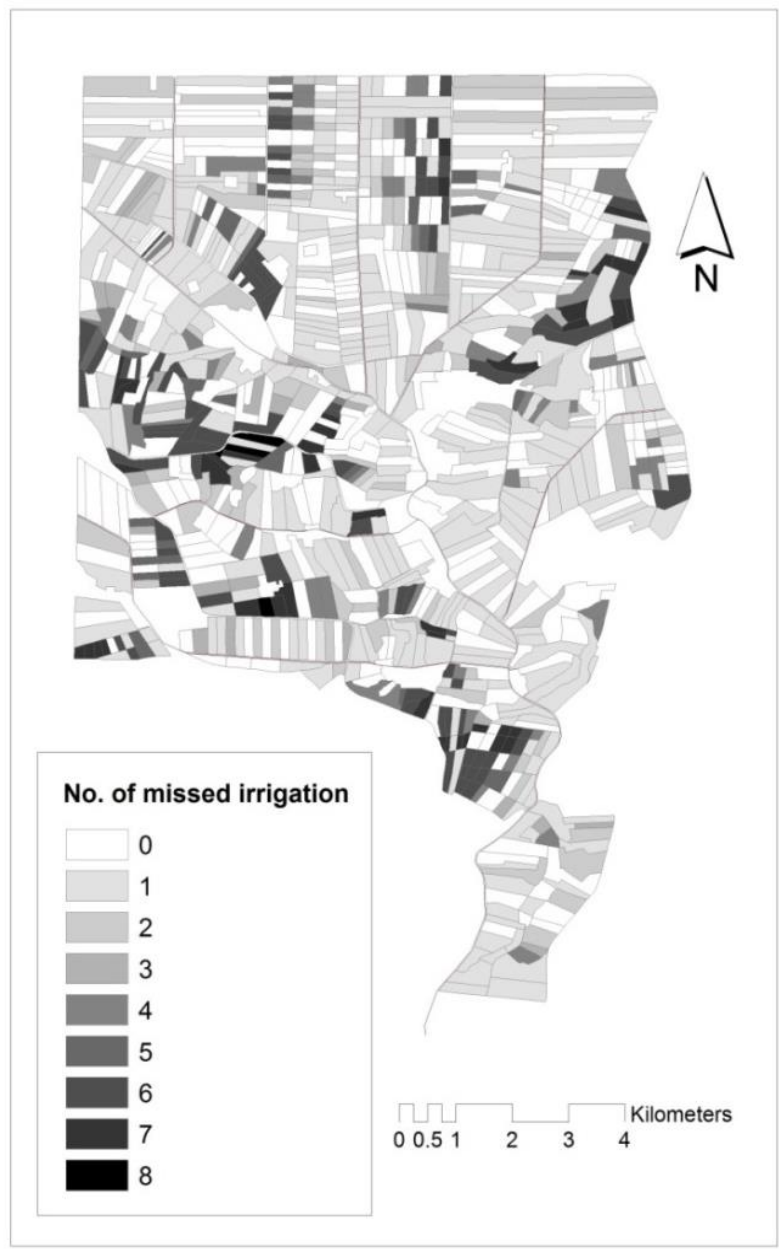

Figure (6): Map for missed irrigation per field for study area 
Fields that missed irrigation under actual cropping pattern are prone to yield shortage. Therefore, it forced to compensate the deficit by draining water. Eventually the crop might be canceled.

\section{Spatial crops manipulation module}

The gross irrigation water depth is obtained from first module "irrigation water requirements calculation" The gross irrigation water depth is saved to the Geodatabase to be used in the next module. The suggested cropping pattern using GIS-OWM and the net area for each crop at the study area for the summer and the winter seasons are shown in figures (7a) and (7b) respectively.

The crops that are suggested by GIS-OWM for the summer season as shown in Figure (7a) are tomato, rice, maize, cucumber, and cotton and its total net areas for each crop are: 100.08, 240.33, 273.47, 109.46, 200.41 Feddans respectively. On a another hand, the GIS-OWM suggested pattern for the winter season as shown in Figure (7b) are wheat, potato, sugar beet, flax, clover, and fababean and its total net areas for each crop are: 2079, 1987, 2289, 836, 3884, 719 feddans respectively.

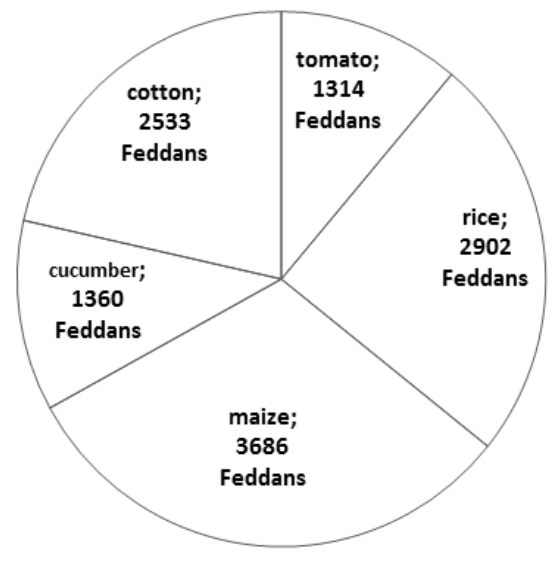

(a)

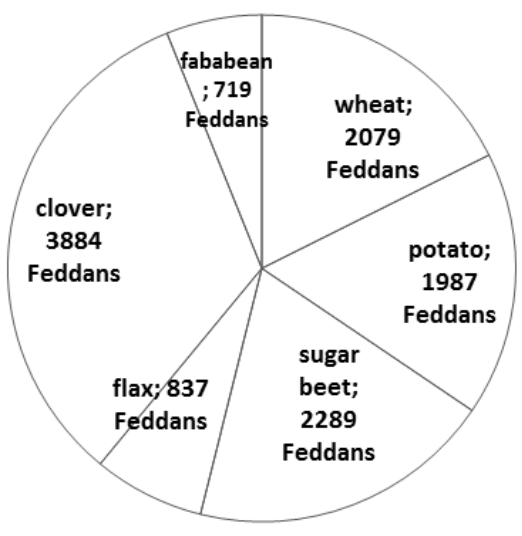

(b)

Figure (7): The suggested cropping pattern using GIS-OWM.

(a) Summer (b) Winter

The output that is obtained from the cropping manipulation tool were verified on the spatial crops manipulation tool in order to determine the 
suitable crops groups for each field using a select tool. The suggested summer and winter crop patterns maps are shown in Figures (8a) and (8b) respectively.

(a)

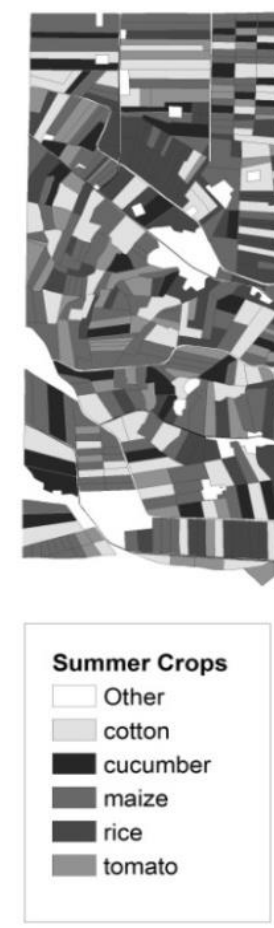

(b)

Figure (8): The maps of the cropping pattern using GIS-OWM.

(a) summer (b) winter

Comparison between the GIS-OWM suggested cropping pattern and the actual cropping pattern

A comparison among (TCAW) $\left(\mathrm{m}^{3}\right)$ the canals available water amount, (Actual TGIR) $\left(\mathrm{m}^{3}\right)$ the gross irrigation requirements for the actual pattern and (GIS-OWM TGIR) $\left(\mathrm{m}^{3}\right)$ the suggested gross irrigation requirements for the pattern manipulated using GIS-OWM for the study area during the summer season were verified for the studied canals. As shown in Figure (9), the GIS-OWM TGIR doesn't exceed the TCAW during all the rotations. The TCAW for each rotation equal approximately 
$2.94 \times 10^{6} \mathrm{~m}^{3}$. The Actual TGIR is higher than the TCAW for rotations 17, 18, 20, 21, 24, and 27.

For example: during rotation no. 17, the TCAW, GIS-OWM TGIR, and actual TGIR are $2.9 \times 10^{6}, 2.3 \times 10^{6}, 3.2 \times 10^{6} \mathrm{~m}^{3}$. The saved water amount for this rotation using GIS-OWM is $8.3 \times 10^{5} \mathrm{~m}^{3}$ for 11795 Feddans, and the persentage of this amount is $28.4 \%$. The saved water amount compared to the actual pattern during summer for the same area when GIS-OWM is verified is $1.22 \times 10^{7} \mathrm{~m}^{3}$. This amount represents about $34.6 \%$ of the total water available during this period.

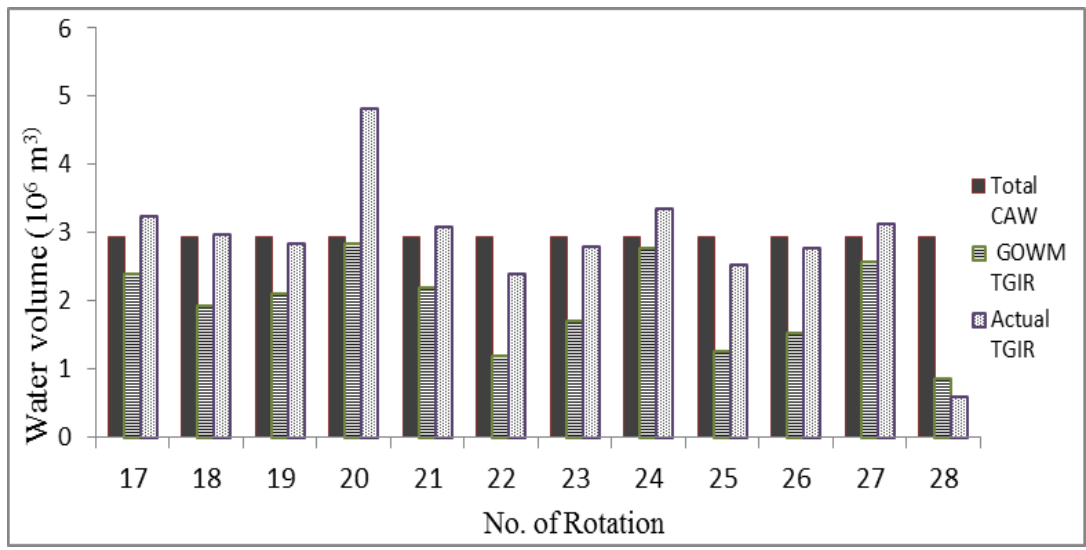

Figure (9): Comparison among the (TCAW) $\left(\mathrm{m}^{3}\right)$, the (Actual TGIR) $\left(\mathrm{m}^{3}\right)$ and the (GIS-OWM TGIR) $\left(\mathrm{m}^{3}\right)$

\section{On- farm Water Allocation module}

GIS-OWM generated dynamic maps for On-farm Water Allocation

GIS-OWM dynamic maps for On-farm Water Allocation are generated for all rotations separately. For example, figure (10) shows the forecasted Onfarm Water Allocation dynamic maps for rotation no. 21. The ON Time is during the period between (29/6/2014 to 1/7/2014). The highest gross irrigation requirements (GIR) that are estimated during the ON Time are $24597 \mathrm{~m}^{3}$ and the lowest are $290 \mathrm{~m}^{3}$. There are 253 Feddans requires from $15357 \mathrm{~m}^{3}$ to $24597 \mathrm{~m}^{3}$. However there are 1575 Feddans requires from 290 $\mathrm{m}^{3}$ to $1967 \mathrm{~m}^{3}$.

There are 210 fields (2673 Feddan) that don't require water on this ON Time, while there are 734 fields (9122 Feddans) that require $2.76 \times 10^{6} \mathrm{~m}^{3}$ of water. Table (3) shows the estimated amount of water is allocated using the GIS-OWM among the 7 canals, the total available water amount 
(TCAW) $\left(\mathrm{m}^{3}\right)$ and the saved water amount $\left(\mathrm{m}^{3}\right)$. The TCAW during the ON Time is $2.94 \times 10^{6} \mathrm{~m}^{3}$ and the total saved water amount is $1.84 \times 10^{5} \mathrm{~m}^{3}$.

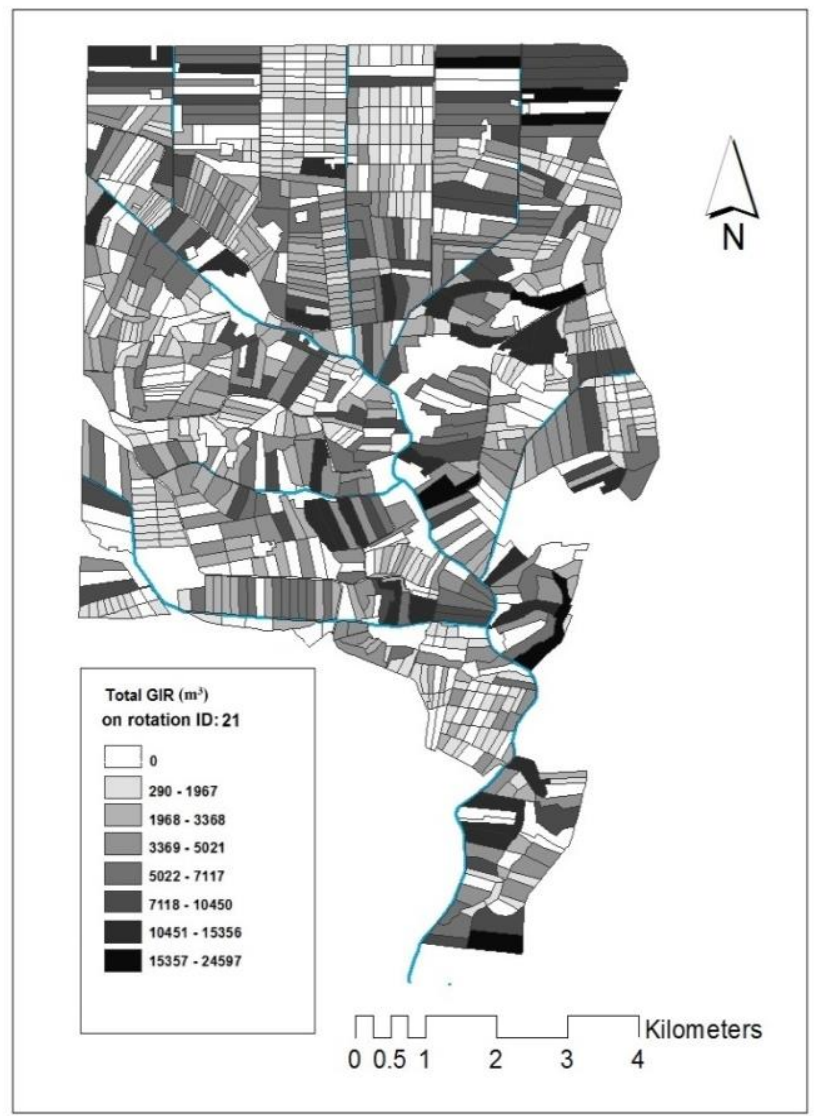

Figure (10): GIS-OWM On-farm Water Allocation dynamic map for rotation NO. 21.

Table (3): Irrigation water allocation using GIS-OWM among the canals on rotation NO. 21.

\begin{tabular}{|c|c|c|c|}
\hline Canal name & TCAW m & GIS-OWM GIR m & Water saved ${ }^{3}$ \\
\hline Bahr elbeshma $^{*}$ & $1.02 \times 10^{6}$ & $9.46 \times 10^{5}$ & $7.39 \times 10^{4}$ \\
\hline Seryowa & $2.40 \times 10^{5}$ & $2.28 \times 10^{5}$ & $1.17 \times 10^{4}$ \\
\hline Elshtoot & $2.80 \times 10^{5}$ & $2.65 \times 10^{5}$ & $1.51 \times 10^{4}$ \\
\hline Habeeb & $2.70 \times 10^{5}$ & $2.15 \times 10^{5}$ & $5.47 \times 10^{4}$ \\
\hline Alkomsewon & $4.60 \times 10^{5}$ & $4.50 \times 10^{5}$ & $9.85 \times 10^{3}$ \\
\hline Elkatf & $4.40 \times 10^{5}$ & $4.31 \times 10^{5}$ & $8.59 \times 10^{3}$ \\
\hline Roos Elferakh & $2.30 \times 10^{5}$ & $2.20 \times 10^{5}$ & $1.01 \times 10^{4}$ \\
\hline Total $^{* *}$ & $2.94 \times 10^{6}$ & $2.76 \times 10^{6}$ & $1.84 \times 10^{5}$ \\
\hline
\end{tabular}

* The amounts of water for the served areas that irrigated directly from Bahr elbeshma canal ** The amounts of water carried by Bahr elbeshma canal for total served area 


\section{GIS-OWM generated dynamic maps of field irrigation status at any time}

The module is also able to generate dynamic maps of field irrigation status at any time. The maps could be changed every one hour. For example: Figure (11) shows the field irrigation status on 21 Feb. 2014 at 9 am during rotation No. 10 (from 20 Feb. 2014 to 24 Feb. 2014). 407 fields are in (Irrigated). 106 fields are (In progress) status and 171 fields are in (non- irrigated). Blank fields refer to fields that didn't need water during this rotation.

The amount of water that was needed during this rotation for fields that have already been irrigated, still in progress, and those that haven't been irrigated yet are $1.08 \times 10^{6}, 6.06 \times 10^{5}$, and $5.13 \times 10^{5} \mathrm{~m}^{3}$ respectively.

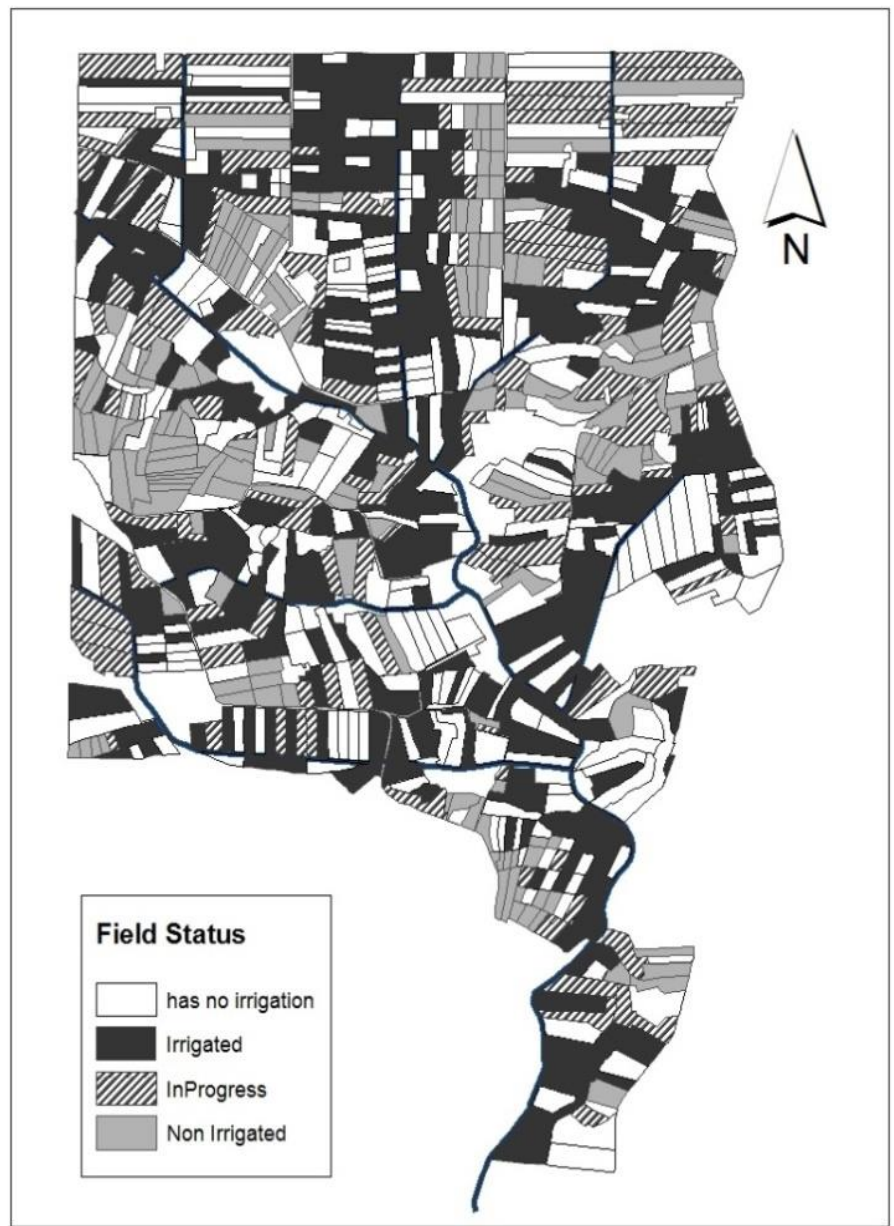

Figure (11): Map generated for field irrigation status using GIS-OWM. 


\section{CONCLUSIONS}

A GIS-Based model is developed for On-farm Water Management (GISOWM). The model includes three modules for water requirements calculations, crops manipulation, and On-farm Water Allocation. The first module "irrigation water requirements calculations" output is the gross irrigation water depth and for each crop. The second module "Crops manipulation" aims to manipulate an optimal crops pattern that insures the amount of total water would be allocated among crops during the season doesn't exceed the available water amount carried by the canal. The third module "On-farm Water Allocation" enables generating maps for On-farm Water Allocation and field irrigation status. The ETo values which is estimated using GIS-OWM were highly significantly correlated with the ETo values that were estimated using FAO CROPWAT. The consumed time to reach the selected gates on Bahr Elbeshma canal using the GIS-OWM model were also highly significantly correlated with the actual consumed time to reach the same gates.

The output which obtained from first module is used in second and so on the third module. The forecasting gross irrigation requirements for the pattern manipulated using GIS-OWM $\left(\mathrm{m}^{3}\right)$ was compared to the canals available water $\left(\mathrm{m}^{3}\right)$ and the gross irrigation requirements for the actual pattern $\left(\mathrm{m}^{3}\right)$. The saved water amount during the summer when the model is applied is $1.22 \times 10^{7} \mathrm{~m}^{3}$ for 11795 Feddans. This amount represents about $34.6 \%$ of the total water available during this period.

The advantages of GIS-OWM can be summarized as the following:

1- Calculating the gross irrigation water requirements

2- Changing cropping pattern to ensure that the available water carried by the canals during ON Times will be adequate for water requirements.

3- Generating dynamic maps for On-farm Allocation and field status maps to accomplish optimal On-Farm Water Management.

\section{REFERENCES}

Ali, M. H. 2011. Practices of Irrigation and On-farm Water Management. Volume 2. Springer. New York. USA. 546 P. 
Allen R.G.; L.S. Pereira, D. Raes and M. Smith. 1998. Crop evapotranspiration guidelines for computing crop water requirements. Irrigation and Drainage, Paper No 56, FAO, Rome, Italy. 300 P.

Ayers, R. S. and D.W. Westcot. 1985. Water quality for agriculture. Irrigation and Drainage Paper No. 29, FAO, Rome, Italy. Available at http://www.fao.org/docrep/003/t0234e/t0234e00.HTM. Accessed on Jan. 2014.

Bandyopadhyay, A.; K. Mahendra and N. S. Raghuwanshi. 2012. Forecasting daily net irrigation requirement maps of India using an ArcGIS toolbar. Ecology and the Environment Journal. Vol. No. 168: pp. $147-158$.

Brouwer, C. and M. Heibloem. 1986. Irrigation Water Management: Irrigation Water Needs. Training Manual No. 3, FAO, Rome, Italy. Available at http://www. fao.org /docrep /s2022e /s2022e00. HTM. Accessed on Jan.2014.

Brouwer, C.; K. Prins and M. Heibloem. 1989. Irrigation Water Management: Irrigation Scheduling Training Manual No. 4, FAO, Rome, Italy. Available at http://www. fao.org/docrep /T7202E/T7202E00. htm Accessed on Jan.2014.

Bustamante, W. O.; J. M. G. Camacho; E. S. Ibarra; E. Isidro and L. R. Pimentel. 2007. Using spatial information systems to improve water management in Mexico. Agricultural Water Management Journal. Vol. No. 89: pp. 81 - 88.

Espana, S.; F. J. Alcala; A. Vallejos and A. Pulido-Bosch. 2011. ArcE: A GIS tool for modelling actual evapotranspiration. Computers \& Geosciences Journal. Vol. No. 37: pp. 1468-1475.

Mandal S. K.. and A. Maity, 2013. Precision Farming for Small Agricultural Farm: Indian Scenario. American Journal of Experimental Agriculture. Vol. No. 3(1): pp. 200-217.

Manna. S. D. 2000. GIS - Based Irrigation Scheduling and On Farm Water Allocation. Unpublished. Ph.D. thesis. Chemical and Bioresource Engineering Dept. Univ. Colorado State. Fort Collins, Colorado. USA. 123 P. 
Ray, S. S. and V.K. Dadhwal. 2000. Estimation of crop evapotranspiration of irrigation command area using remote sensing and GIS. Agricultural Water Management Journal. 49 (3): pp. 239 - 249.

Smith, M. 1992. CROPWAT A computer program for irrigation planning and management. Irrigation and Drainage Paper No. 46, FAO, Rome, Italy. $125 \mathrm{P}$.

Todorovic, M. and P. Steduto. 2003. A GIS for irrigation management. Physics and Chemistry of the Earth Journal. Vol. No. 28: pp. 163174.

Wen, T. H.; M. D. Su and Y. L. Yeh. 2004. A GIS-based framework of regional irrigation water demand assessment. Paddy and Water Environment Journal. 2 (1): 33-39.

Wong. A. W. 2004. Spatial Allocation of Irrigation Water in an Agricultural Watershed Using GIS. Unpublished M.Sc. thesis. Fac. of Graduate Studies. Guelph Univ. Canada. 169 P.

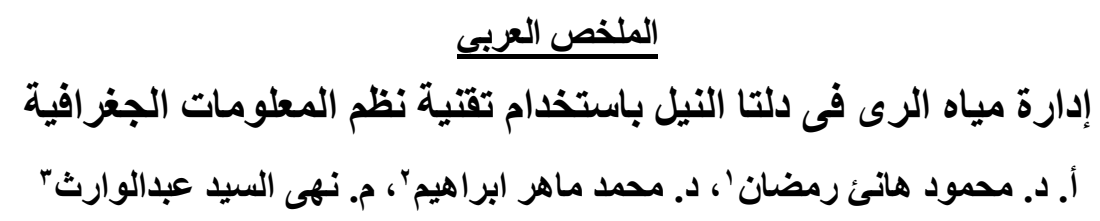

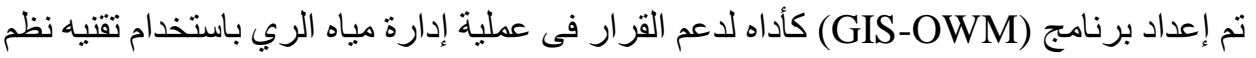

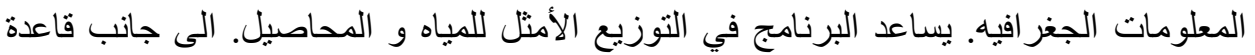

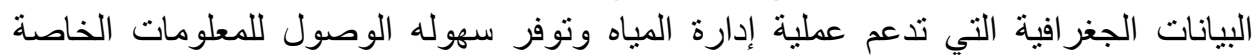
بالمنطقة. حيث ينقسم لثناثة مر احل: ا ـالمرحلة الأولى: حساب الاحتباجات المائية للمحاصيل: حيث يمكن الحصول على مواعيد الريات وكميات المياه المطلوبه في كل رية ويتم تخزين

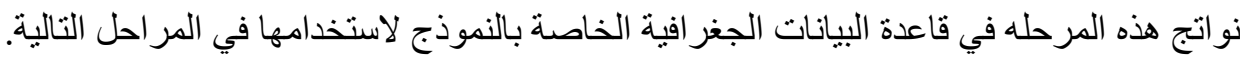

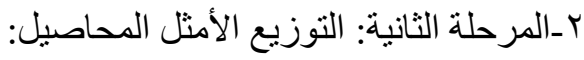
وفيها يتم توزيع المحاصيل بحيث لا يزيد مجموع الاحتياجات المائية اللازم إضافتها

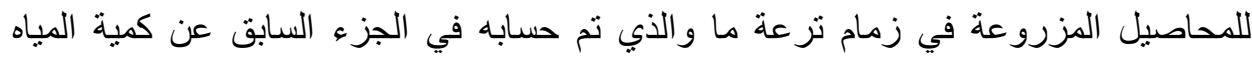
المنوفرة في الترع في دور العمالة الى جانب التوزيع المكاني على خريطه فئ المنطقه ويكون الناتج

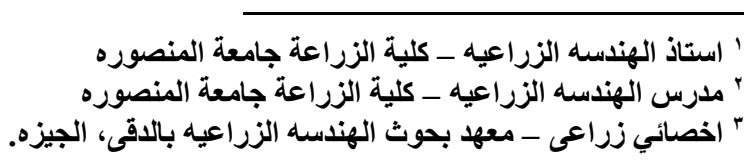


في هذه المرحلة خر ائط لتوزيع المحاصيل في الزمام المدخل تظهر للمستخدم ويمكن استخدامها

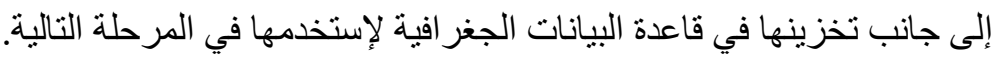

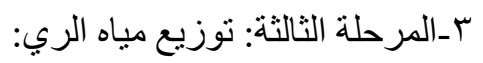

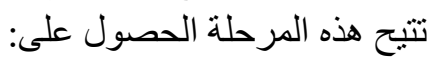

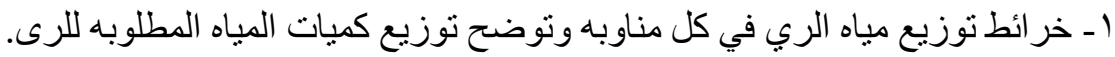

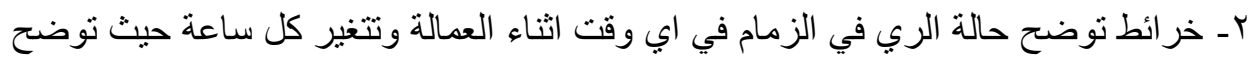
المساحات التي تم ريها و المساحات التي لاز الت في عملية الري التي والت المساحات الى لم ينم ريها

$$
\text { بعد }
$$

rـ بيانات التز ع و الأر اضي وذللك بالضغط عليها بأدو ات مخصصه حيث يتم التعرف على بيانات التيات

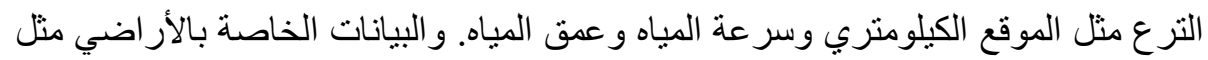

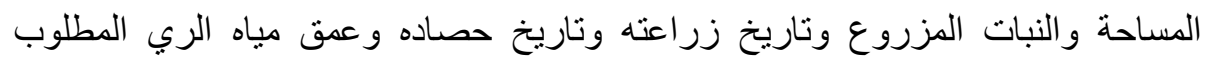

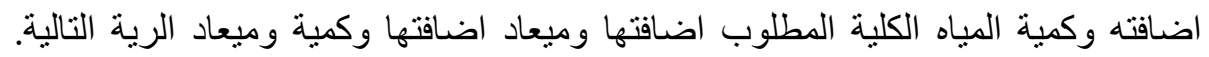

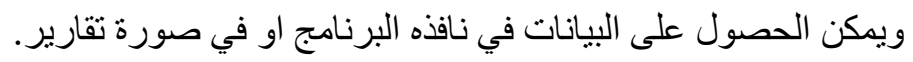

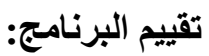

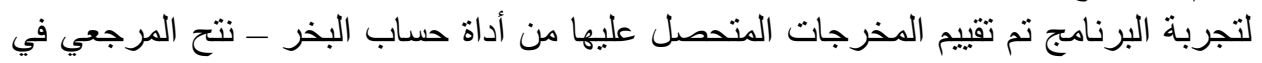

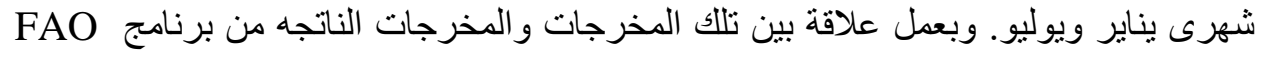

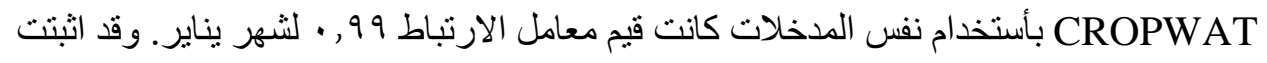

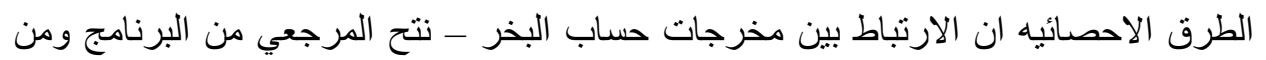

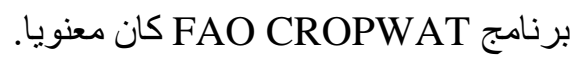

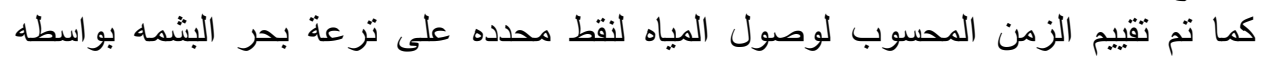

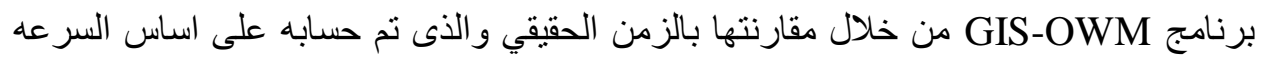

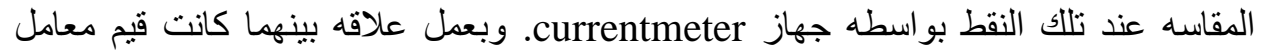
الارنباط 0.99. وقد اثتتت الطرق الاحصائيه ان الارتباط بينهما معنويا.

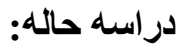

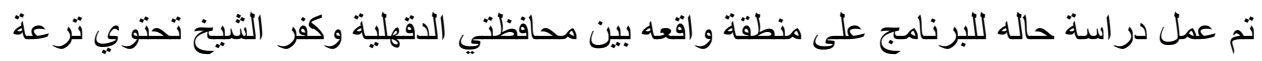

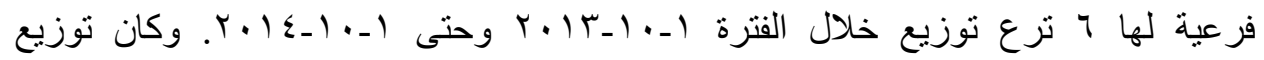

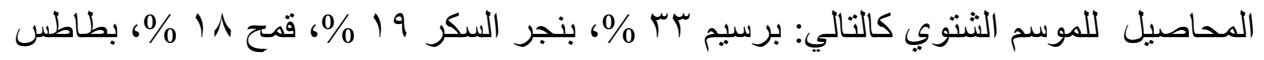

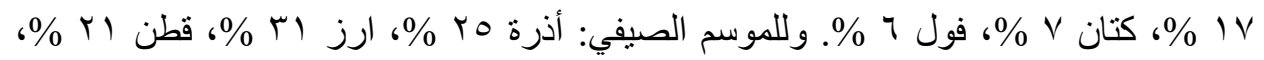

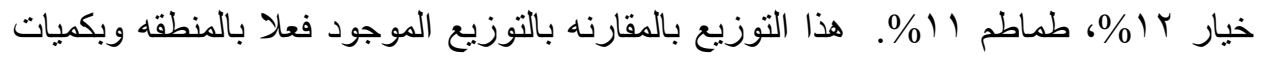

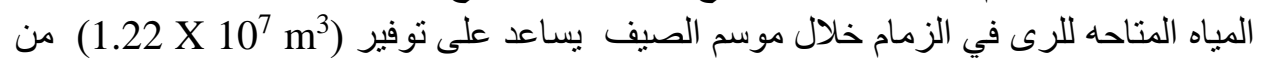

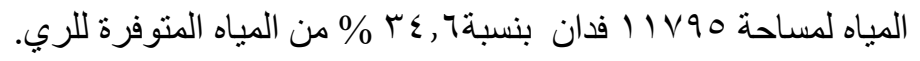

